[Note]

\title{
Sterilization Conditions of the Autoclave Equipped in the Breeding Section of Laboratory Animal \\ Center, Institute of Medical Science, University of Tokyo.
}

\author{
Kazuyoshi MAEJIMA, Kiyoshi SUZUKI, Rizo KOBAYASHI, \\ Katsuko SUDO and Kikuji ITOH \\ Institute of Medical Science, University of Tokyo, Takanawa P. O., Tokyo
}

(Received for publication : December 5, 1972)

The conditions of sterilization were examined for preparing the aseptic materials using the autoclav e equipped in the Breeding Section of Laboratory Animal Center. Sterilized diets could be prepared by autoclaving at $115^{\circ} \mathrm{C}$ for $30 \mathrm{~min}$, at $120^{\circ} \mathrm{C}$ for $20 \mathrm{~min}$ or at $125^{\circ} \mathrm{C}$ for $15 \mathrm{~min}$. Food intake and body weight increase in mice given the autoclaved diet were not different from those given untreated diet, although dietary vitamin $B_{1}$ contents reduced to $20-50 \%$ of untreated diet after autoclaving. A longer period of autoclaving was necessary to sterilize the drinking water, because of a large value in the specific heat of water. In practice, sterilization of water was required for autoclaving at $120^{\circ} \mathrm{C}$ for $90 \mathrm{~min}$, while the sterilization of bedding, cage and other materials as well as diet for autoclaving at $120^{\circ} \mathrm{C}$ for $20 \mathrm{~min}$. [Exp. Animals, 22(1), 31-36, 1973]

\section{東京大学医科学研究所動物センター繁殖室に設置された オートクレーブの滅菌条件に関する検討 \\ 前島 一淑・鈴木 潔・小林 理造・須藤カッ子・伊藤喜久治 東京大学医科学研究所 \\ （1972年12月 5 日受付）}

1970年12月に竣工した東大医科研動物センター（以下 センター）の 4 階は, SPF ならびに無菌動物の繁殖室 にあてられ, そこに供給される器材の滅菌のため日東理 科工業製の両扉式全自動高圧蒸気滅菌装置, ユニクレー ブ UC-202B (以下オートクレーブ) が設置されている。 ここの運営は1971年12月からはじまったが, 将来無菌動 物のために，200台以上のアイソレータが用いられると 予想される。そこで, ここのオートクレーブで各種の器 材を隇菌する方法について，あらかじめ十分な検討を加 えておくことにした。えられた知見にはセンター内部で のみ通用するデータもあるが, 無菌動物の飼育を新しく はじめようとするときに役立つデータもすくなくないと
考え，その大要を記述することにした。

まず，滅菌操作について簡単に説明しておく。固型飼 料は金了ミ製の棚に一層にならべ，床敷き（おがくず） は布製の袋に軽くつめ, 飲水は $500 \sim 700 \mathrm{~m} l$ の角ビンに いれケージに立て，それぞれ $315 \mathrm{~mm}$ 径のフィルターメ デアを巻いたステンレス鋼製の缶 (以下滅菌缶) に納め, ロをマイラー膜で封じる。その操作は, 医科研で日常化 されている作業手順（前島他：ビニールアイソレータの 組立と操作。瑞穂印刷, 1969) に従っている。

オートクレーブは全行程が自動である。始動ボタンを 押すとオートクレーブ内筒が減圧され，内圧 - 55〜65 $\mathrm{cmHg}$ の状態が 5 分保たれ，ついで $2 \mathrm{~kg} / \mathrm{cm}^{2}$ 程度に減 
Table 1. Bacteriological checking on the autoclaved diets 1 .

\begin{tabular}{|c|c|c|c|c|c|c|c|}
\hline \multicolumn{2}{|c|}{$\begin{array}{l}\text { Series of examination } \\
\text { Autoclaving }\end{array}$} & I & II & III & IV & V & Total \\
\hline \multicolumn{2}{|c|}{$110^{\circ} \mathrm{C}$ for $20 \mathrm{~min}}$. & $20 / 20^{*}$ & $20 / 20$ & $-{ }^{* *}$ & - & - & $40 / 40$ \\
\hline "l & 30 & $20 / 20$ & $20 / 20$ & - & - & - & $40 / 40$ \\
\hline 115 & 15 & $4 / 20$ & $7 / 20$ & $20 / 20$ & - & - & $31 / 60$ \\
\hline$\prime \prime$ & 20 & $16 / 20$ & $3 / 20$ & $0 / 20$ & - & - & $19 / 60$ \\
\hline$\prime \prime$ & 25 & $0 / 20$ & $0 / 20$ & $0 / 20$ & $0 / 20$ & $0 / 20$ & $0 / 100$ \\
\hline " & 30 & $0 / 20$ & $0 / 20$ & $0 / 20$ & $0 / 20$ & $0 / 20$ & $0 / 100$ \\
\hline 120 & 10 & $0 / 20$ & $12 / 20$ & $14 / 20$ & - & - & $26 / 60$ \\
\hline "I & 15 & $0 / 20$ & $0 / 20$ & $0 / 20$ & $0 / 20$ & $0 / 20$ & $0 / 100$ \\
\hline$\prime \prime$ & 20 & $0 / 20$ & $0 / 20$ & $0 / 20$ & $0 / 20$ & $0 / 20$ & $0 / 100$ \\
\hline 125 & 5 & $20 / 20$ & $3 / 20$ & $7 / 20$ & - & - & $30 / 60$ \\
\hline "I & 10 & $0 / 20$ & $0 / 20$ & $0 / 20$ & $0 / 20$ & $0 / 20$ & $0 / 100$ \\
\hline "I & 15 & $0 / 20$ & $0 / 20$ & $0 / 20$ & $0 / 20$ & $0 / 20$ & $0 / 100$ \\
\hline
\end{tabular}

* No. positive / examined.

** Not examined.

Table 2. Bacteriological checking on the autoclaved diets 2 .

\begin{tabular}{|c|c|c|c|c|c|}
\hline \multirow{2}{*}{$\begin{array}{l}\text { Incubation } \\
\text { temperature } \\
\text { (for 14 days) }\end{array}$} & \multicolumn{2}{|c|}{$\begin{array}{l}\text { Thioglycollate } \\
\text { medium }\end{array}$} & \multicolumn{2}{|c|}{$\begin{array}{l}\text { Cooked meat } \\
\text { medium }\end{array}$} & \multirow{2}{*}{$\begin{array}{c}\begin{array}{c}\text { Potato dextrose } \\
\text { broth }\end{array} \\
\text { Room } \\
\text { temp. }\end{array}$} \\
\hline & $37^{\circ} \mathrm{C}$ & $\begin{array}{l}\text { Room } \\
\text { temp. }\end{array}$ & $37^{\circ} \mathrm{C}$ & $\begin{array}{l}\text { Room } \\
\text { temp. }\end{array}$ & \\
\hline $115^{\circ} \mathrm{C}$ for $30 \mathrm{~min}$. & $0 / 60^{*}$ & $0 / 60$ & $0 / 60$ & $0 / 60$ & $0 / 60$ \\
\hline 120 & $2 / 120^{* *}$ & $0 / 120$ & $0 / 120$ & $0 / 120$ & $0 / 120$ \\
\hline 125 & $0 / 60$ & $0 / 60$ & $0 / 60$ & $0 / 60$ & $0 / 60$ \\
\hline
\end{tabular}

* No. positive / examined.

** Heat labile gram positive cocci and cocco-bacilli.

圧された蒸気が外筒に導入される。外筒で凝縮された水 はそのままオートクレーブ外に排出され，飽和蒸気の みがゆっくり内筒へ導入される。内筒の温度があらかじ め設定された温度になると, 蒸気の導入は一時的にとま りタイマーが作動する。内筒温度が下ると入気弁が 開 き，上れば閉じ，温度による蒸気圧制御が括こなわれ る。所定の時間になれば入気并は閉じ，蒸気は排気機構 の作動で排出され，沪過無菌空気が急速に導入される。

固型飼料の滅菌：まず, $110,115,120,125^{\circ} \mathrm{C}$ と 5,10 , $15,20,25,30$ 分の処置をく又あわせた 12 種の条件を定め, オリエンタル酵母製の NMF 飼料の滅菌を試みた。各 処置ごとに $20 コ の$ 飼料を別々の 20 本の heart infusion broth (Difco, $20 \mathrm{~m} l$, 以下 H I ブイヨン) に投じ, $37^{\circ}$ C 7 日の好気的培養を㨟こなった。この検索は 2,3 な いし 5 回くりかえしたので, 各処置ごとの培養試料数は 40，60ないし100である。

Table 1. はその成績のまとめであるが， $110 \mathrm{C}^{\circ}$ では
30分のオートクレーブ処置を加えても 40/40 コの飼料か ら菌が検出された。また， $115^{\circ} \mathrm{C} 20$ 分で $19 / 60$ コ， $120^{\circ}$ $\mathrm{C} 10$ 分で $26 / 60$ コ, $125^{\circ} \mathrm{C} 5$ 分で $30 / 60$ コの飼料が培養 試験陽性であった。陽性 186 例について菌が検出される までの培養日数をみると， $1,2, \cdots \cdots, 7$ 日の累積陽性 数は $27,72,110,136,154,184,186$ で，ここで陰性とされ た試料からもさらに長時間培養すれば，菌が検出された かもしれない。そこでとりあえず，各温度ごとに 5 分の 安全巾をみこみ, 固型飼料が滅菌できるオートクレーブ 処置は $115^{\circ} \mathrm{C} 30$ 分, $120^{\circ} \mathrm{C} 20$ 分または $125^{\circ} \mathrm{C} 15$ 分とし た。

これらの条件によるオートクレーブ処置を，NMF 飼 料のほかにオリエンタル酵母製の CMF 飼料, 船橋農場 製の F I ならびに F II 飼料の 4 種類の固型飼料について 試み，各20コずつの試料を別々の 20 本の H I ブイヨンに 投じ， $37^{\circ} \mathrm{C}$ で好気的に14日培養した。この検索は各飼 料とも 3 lot についておこなったが全例陰性であった。 
以上の検索は H I ブイヨンによる好気的培養だけで括 こなわれ，必ずしも十分な培養試験とはいえない。そこ で, 実験動物研究会・無菌試験の規準に関する委員会の 試案（実験動物，21，35３8，1972）に準拠し， clinical thioglycollate medium(Eiken), $0.1 \%$ 寒天加 cooked meat medium (Eiken), potato dextrose broth (PD agar, Eiken から寒天を除いたもの) を用意し， $37^{\circ} \mathrm{C}$ および室温 $\left(24 \sim 26^{\circ} \mathrm{C}\right)$ で培養を試みた。被検試料は NMF 飼料のみで, その成績は Table 2. と示したが, $120^{\circ} \mathrm{C} 20$ 分処置試料を thioglycollate medium で37 C培養した場合にのみ $2 / 120$ 例が陽性であった。しかし ここでえられた菌は, グラム陽性球菌とグラム陽性球桿 菌で，いずれも $60^{\circ} \mathrm{C} 30$ 分の加熱に抵抗できず，培養操 作時の污染菌と思われる。

ところで, 培養試験に扔いて試料は砕くことなく液体 培地に投じそのまま培盖するため，運動性を欠く菌が飼 料の内部に生残した場合検出できないかもしれない。し かし，上記の 3 条件でオートクレーブ処置した NMF飼 料を12匹（2 匹ずつ6 台のアイソレータに収容）の無菌 マウスに与えたが，無菌状態を 3 力月以上維持できたの で，菌が生残している可能性はまずないとみてよい。

これらの成績は, 固型飼料が $115^{\circ} \mathrm{C} 30$ 分, $120^{\circ} \mathrm{C} 20$ 分あるいは $125^{\circ} \mathrm{C} 15$ 分のオートクレーブ処置で滅菌でき ること, 飼料の滅菌可否の検討には, H I ブイヨン $37^{\circ} \mathrm{C}$ 14日の好気的培養試験でお拈よそ判断はできることを示 す。
飼料由来 Bacillus の耐熱性：まず，NMF 飼料とFI 飼料 $1 \mathrm{~g}$ あたりの好気性菌の生菌数（M. \pm S. D., N= 20)を H I 寒天でしらべたところ, $10^{3.0 \pm 0.5, ~ 103.1 \pm 0.3 て ゙, ~}$ その大部が Bacillus, 残りは Micrococcus, 酵母, グ ラム陰性桿菌であった。嫌気性培養による菌数は, いず れも好気性菌の $1 / 10$ 以下であった。この飼料を砕きPBS に懸濁させ $100^{\circ} \mathrm{C} 10$ 分加熱すると, H I ブイヨンを用い た好気性培養で菌が検出される NMF 飼料は $6 / 20$ 二, $\mathrm{F} I$ 飼料は7/20コにすぎず， $100^{\circ} \mathrm{C} 20$ 分加熱すると全例 除性となった。

つぎに，30株の Bacillusをこれらの飼料から無作為 的に採取し, H I 寒天で $37^{\circ} \mathrm{C} 3$ 日培養し芽胞を形成さ

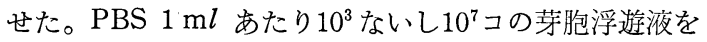
つくり, 外径 $10 \mathrm{~mm}$ の小試に $0.5 \mathrm{~m} l$ ずつ分注し, $100^{\circ}$ Cのふっとら水中につけ10分执きととりだし，その全容 を H I ブイヨンに移し $37^{\circ} \mathrm{C} 14$ 日培養を执こなった。そ の結果, $7 / 30$ 株は $100^{\circ} \mathrm{C} 10$ 分の加熱に耐兄られなかっ たが，10/30 株は 30 分以上, とくに 4 株は 120 分の加熱 に耐えた。しかし，この 4 株ならびにアイソレータの菌 污染事故に由来寸る保存 Bacillus 25 株の 芽胞につい て, $110,115,120^{\circ} \mathrm{C}$ で各10分のオートクレーブ処置を 加えたところ，すべて $110^{\circ} \mathrm{C} 10$ 分の加熱に抵抗できなか った。

これらの成績は, Bacillus ないしその芽胞の浮遊液 を用いた加熱処置に関するデータと実際に飼料をオート クレーブ処置した場合の成績にはくい違いがあることを

Table 3. Vitamin $B_{1}$ and $B_{2}$ contents in the autoclaved diets.

\begin{tabular}{|c|c|c|c|c|c|c|}
\hline \multirow{2}{*}{ Pellets } & \multirow{2}{*}{$\begin{array}{l}\text { Series of } \\
\text { examination }\end{array}$} & \multirow{2}{*}{ Autoclaving } & \multicolumn{2}{|r|}{ V. $B_{1}$} & \multicolumn{2}{|r|}{ V. $\mathrm{B}_{2}$} \\
\hline & & & $\mathrm{mg} \%$ & Retention $\%$ & $\mathrm{mg} \%$ & Retention $\%$ \\
\hline \multirow[t]{4}{*}{$\mathrm{NMF}$} & I & $115^{\circ} \mathrm{C}$ for $30 \mathrm{~min}$. & 0.84 & 43.5 & 1.28 & 93.4 \\
\hline & & $120 \quad 20$ & 0.60 & 31.1 & 1.31 & 95.6 \\
\hline & & $125 \quad 15$ & 0.58 & 30.1 & 1.24 & 90.5 \\
\hline & & untreated & 1.93 & - & 1.37 & - \\
\hline \multirow[t]{4}{*}{$\mathrm{CMF}$} & I & $115^{\circ} \mathrm{C}$ for $30 \mathrm{~min}$ & 1.25 & 44.2 & 2.80 & 93.3 \\
\hline & & $120 \quad 20$ & 0.98 & 34.6 & 2.83 & 94.3 \\
\hline & & 125 & 0.94 & 33.2 & 2.77 & 92.3 \\
\hline & & untreated & 2.83 & - & 3.00 & - \\
\hline \multirow[t]{4}{*}{ NMF } & II & $115^{\circ} \mathrm{C}$ for $30 \mathrm{~min}$. & 0.84 & 32.7 & 1.66 & 104.4 \\
\hline & & $120 \quad 20$ & 0.75 & 29.2 & 1.51 & 95.0 \\
\hline & & $125 \quad 15$ & 0.52 & 20.2 & 1.51 & 95.0 \\
\hline & & untreated & 2.57 & - & 1.59 & - \\
\hline \multirow[t]{4}{*}{ F I } & II & $115^{\circ} \mathrm{C}$ for $30 \mathrm{~min}$. & 1.04 & 49.8 & 0.73 & 84.9 \\
\hline & & $120 \quad 20$ & 0.93 & 44.5 & 0.65 & 75.6 \\
\hline & & $125 \quad 15$ & 0.70 & 33.5 & 0.70 & 81.4 \\
\hline & & untreated & 2.09 & - & 0.86 & - \\
\hline
\end{tabular}




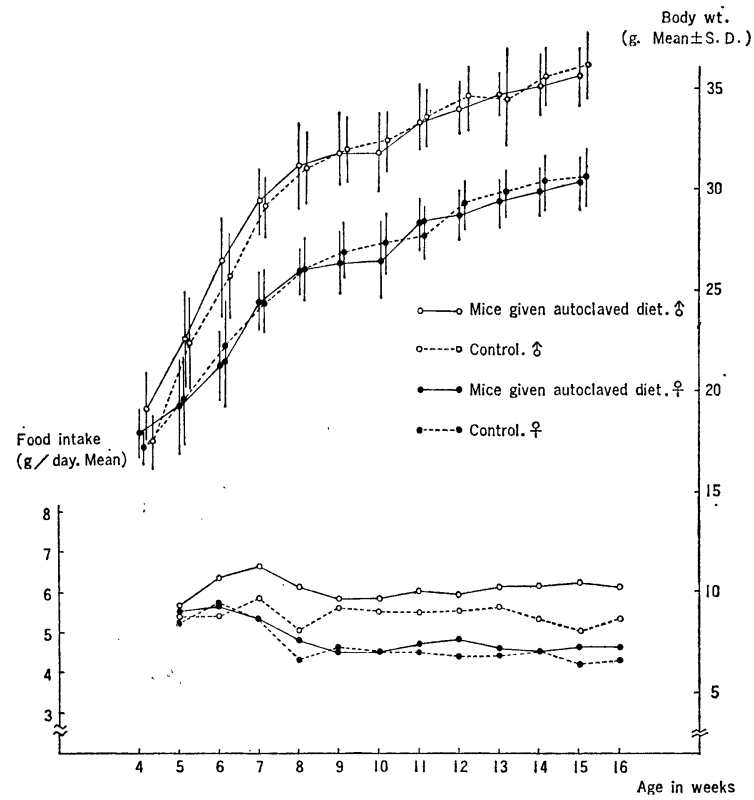

Fig. 1 Food intake and body weight increase in conventional DDD mice given the autoclaved diet

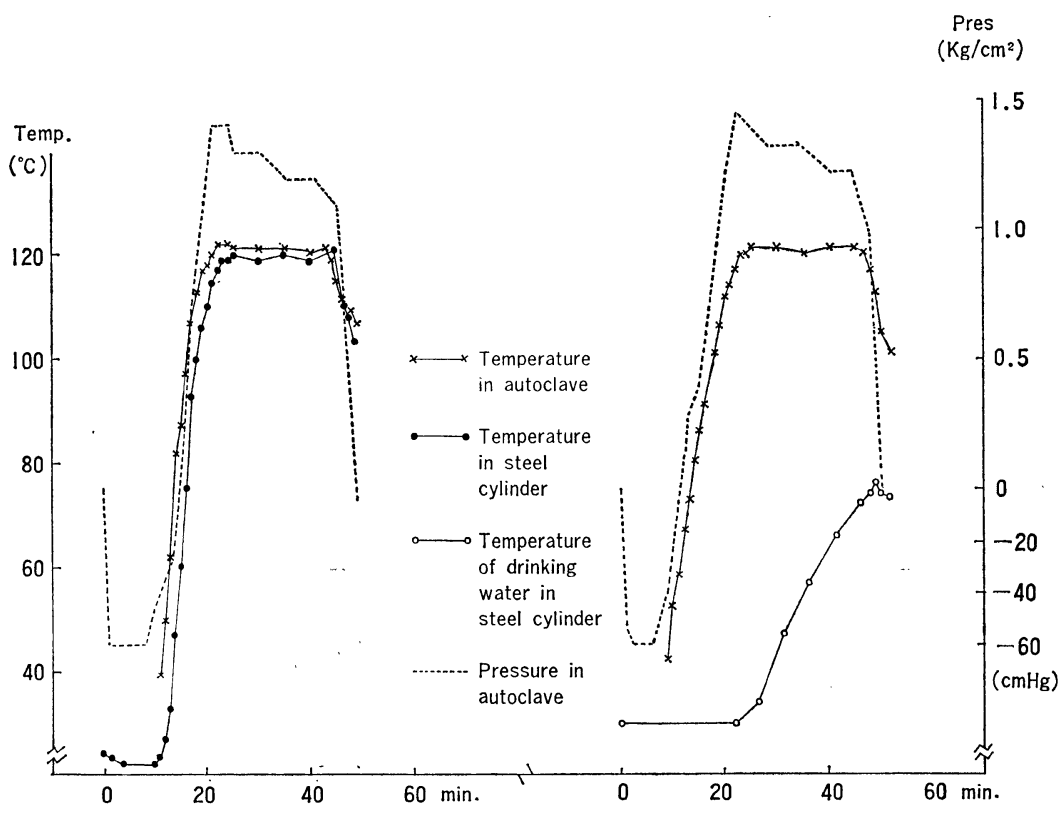

Fig. 2 Temperature and pressure in autoclave 


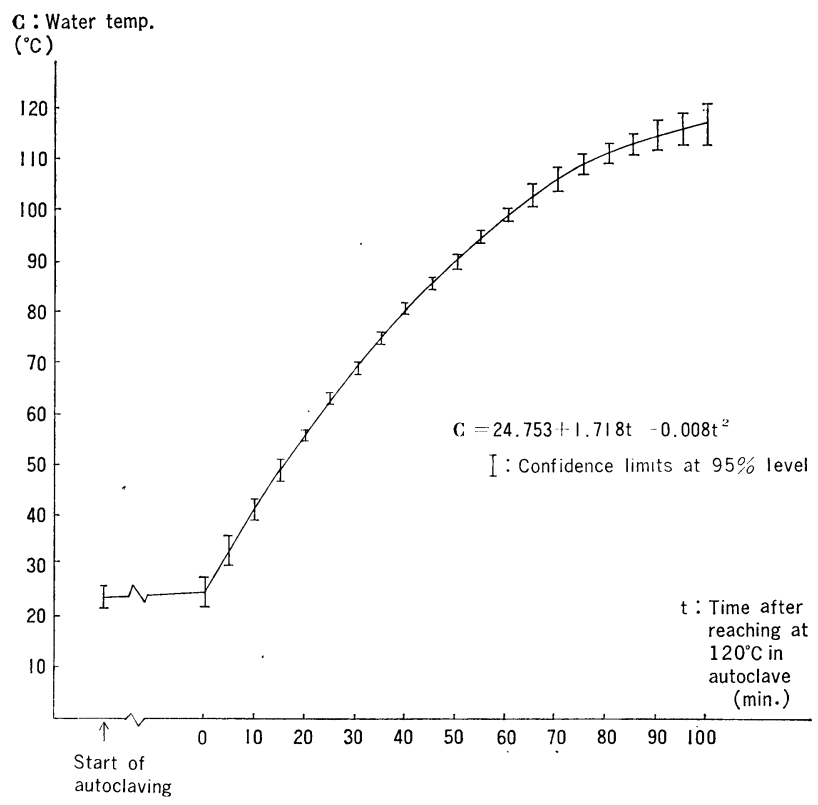

Fig. 3 Temperature of drinking water after reaching at $120^{\circ} \mathrm{C}$ in the autoclave

示唆している。つまり, 飼料の滅菌条件については, 飼 料を実際にオートクレーブで処置して検討すべきであろ ら。

飼料ビタミンの破損と摂䬲量 : 飼料滅菌のためのオ一 トクレーブ処置として, $115^{\circ} \mathrm{C} 30$ 分, $120^{\circ} \mathrm{C} 20$ 分あるい は $125^{\circ} \mathrm{C} 15$ 分といら条件が設定できたと前述したが，飼 料成分の破損状況がこの 3 種の条件のあいだで異なって いるかもしれない。そこで, 検索の対象としてビタミン $\mathrm{B}_{1}$ とビタミン $\mathrm{B}_{2}$ をとりげ, $\mathrm{NMF}$ 飼料, $\mathrm{CMF}$ 飼料沶 よび F I 飼料を上述の 3 条件でオートクレーブ処置した のち, 定量を日本科学飼料協会に依頼した。Table 3 に 示すように，ビタミン $\mathrm{B}_{1}$ の破損は処置温度が低いほどす くない傾向にあったが，その差はとくに大きくはなかっ た。また，ビタミン $\mathrm{B}_{2}$ の破損はわずかであった。

ついで，滅菌飼料の摂取量について検討した。Fig. 1 は, $120^{\circ} \mathrm{C} 30$ 分オートクレーブ処置 NMF 飼料を 12 週間 にわたり与えたふつらの DDD マウスに拈ける掑䬣量な らびに体重の推移であるが，主早とも無処置群とのあい
だに差はみられなかったといえる。この知見は, 飼料滅 菌の条件は, むしろオートクレーブ作業のしやすさに重 点を沶いて決めればよいことを示している。そしてわれ われは, $120^{\circ} \mathrm{C} 20$ 分のオートクレーブ処置を, 無菌動物 用飼料の滅菌のための日常作業と決めた。

飲水の滅菌：水は比熱が大きいため, 飼料の場合にく らべて水のオートクレーブ滅菌には, 長時間の加熱が必 要となる。滅菌缶内の温度の推移を, 缶内に挿入したサ 一ミスタ温度計によってしらべると, Fig. 2-aのように なった。参考までに, 内筒温度ならびに圧力をあわせ示 したが, 減菌缶内の温度は, 内筒の温度とほぼ平行して 上昇した。さて, 飲水を隇菌缶に納め, $120^{\circ} \mathrm{C} 20$ 分オ一 トクレーブ好置を加えて飲水温度の推移を記録したのが Fig. 2-b であるが, 滅菌缶内の水温の上昇はきわめて ゆるやかであった。内筒温度が $120^{\circ} \mathrm{C}$ に達したときよう やく $30^{\circ} \mathrm{C}$ 前後, 滅菌行程が 終了したときでも $70^{\circ} \mathrm{C} に$ すぎなかった。このことは, 飼料滅菌と同じ方法によっ ては飲水の滅菌ができないことを示している。事実, 当 
初センターでは飲水を $120^{\circ} \mathrm{C} 30$ 分という条件でオートク レーブ好置したが，これを与えていた無菌マウスの菌污 染率は65\%（アイソレータあたり）をこえていた。な お, センターにオートクレーブが設置される以前は, 器 材の滅菌に培地室のオートクレーブを利用していたが, その時期の菌污染率は $3 \%$ 以下であった。それは, 培地 室のオートクレーブの蒸気の導入はきわめてゆるやか で, $120^{\circ} \mathrm{C}$ 到達するのに60分以上を要し, 滅菌缶内の 水温と内筒温度がほぼ平行していたためと思われる。す なわち, センターに設置されたオートクレーブでは, 蒸 気の導入が急速すぎるといえる。

そこで, サーミスタ温度計とタイマーを連動させ, 飲 水の温度が $120^{\circ} \mathrm{C}$ 達してから 15 分オートクレーブ処置 ができるように改造した。ところが，温度によって圧力 が制御される機構のため, 始動後約 40 分で内筒蒸気圧は 約 $2 \mathrm{~kg} / \mathrm{cm}^{2}$, 温度は $130^{\circ} \mathrm{C}$ 前後まで上昇してしまっ た。そして, 水温が $120^{\circ} \mathrm{Cに}$ 達するのに約 90 分を要し, タイマー作動と同時に蒸気弁が閉じ, 内筒の温度と圧力 は $120^{\circ} \mathrm{C}, 1.2 \mathrm{~kg} / \mathrm{cm}^{2}$ 前後まで下降した。この方法は, 水の滅菌のために完全なものではあるが，一時的に圧力 と温度が高くなり, オートクレーブや隇菌缶を傷つけ, さらに 1 回ごとに温度計を滅菌缶内の飲水中に挿入しな ければならないため，望ましいものではない。

ところで, 飼料にふくまれる Bacillus の耐熱性を検 討したとき, $\mathrm{PBS}$ に浮遊させた芽胞は $110^{\circ} \mathrm{C} 10$ 分の加熱 に抵抗できなかった。また熱によって破䁁されやすい成 分をふくも培地の滅菌には, $110^{\circ} \mathrm{C} 10$ 分処置がしばしば 用いられる。そこで飲水も確実に $110^{\circ} \mathrm{C} 10$ 分加熱すれば 滅菌できるかもしれないと考えた。さらに, 温度計の飲 水への挿入拉びタイマーとの連動は繁雑であるから,
できるならば省略したい。そこで, 反復して種々のオ一 トクレーブ好置を試みた。Fig. 3 は, 内筒温度を $120^{\circ}$ Cに設定したときの滅菌缶内の水温の上昇曲線を示して いるが，滅菌時間を90分と設定すれば，飲水は $110^{\circ} \mathrm{C}$ 以 上で10分加熱される。この条件で隇菌した飲水を 8 台の アイソレータ（無菌マウスは計30匹以上収容）に 2 力月 供給したがマウスは無菌状態で維持された。なお, 飲水 のオートクレーブ処置に関する検討には, サーミスタ温 度計を特別に装着しなくとも，留点温度計を用いて，一 定時間ごとにオートクレーブを止めて反復検索すればよ い。

床敷きその他の器材の滅菌 : 無菌動物飼育のために は, 飼料と飲水のほかに床敷き, ケージ, フィルターな ぞが，オートクレーブ滅菌されることが多い。床敷さ （おがくず）について, 飼料と同様 $120^{\circ} \mathrm{C} 20$ 分のオート クレーブ処置を加え，その木片を 100 コずつ H I ブイヨ ンならびに potato dextrose broth に投じ， $37^{\circ} \mathrm{C}$ な らびに室温で14日間培養してみたが，いずれも陰性であ った。その他の 器材についての 培養試験は試みてない が，これらがとくに滅菌されがたいとする理由はみあた らない。実際に水以外の器材をすべて $120^{\circ} \mathrm{C} 20$ 分処置し て無菌マウスに与えてみたが，いささかの支障もきたさ なかった。

なお，オートクレーブには圧力と温度についての自動 記録装置がついていたが，その精度はあまりよいもので はない。むしろ加熱状態を示す“タイムカード”，ない し“タイムテープ” のほうが信頼できそうである。われ われは, 各種のタイムカード・タイムテープを比較検討 したが，製品あるいは lot のあいだの差はわずかであっ たことを附記しておく。 